\title{
The role of physical activity in counteracting
} age-related sarcopenia and cancer cachexia. A brief literature review Uloga fizičke aktivnosti u suzbijanju sarkopenije
povezane sa starenjem i kaheksije kod
karcinoma - kratak pregled literature

\author{
Mattia Scalabrin ${ }^{1}$, Daniela Caporossi ${ }^{2}$
}

${ }^{1}$ European Master in Health and Physical Activity, University of Rome "Foro Italico", Rome, Italy
${ }^{2}$ Department of Movement, Human and Health Sciences, University of Rome "Foro Italico", Rome, Italy

Contact: m.scalabrin@uniroma4.it

\begin{abstract}
Muscle tissue plays several important health functions. In addition to the important mechanical functions, it represents the biggest reserve of body proteins and it is also able to produce several myokines that are able to induce important beneficial effects, through the interaction with different organs. The loss of muscle mass has a tremendous impact on health and it is not surprising that a great interest has raised on two degenerative, irreversible and unstoppable conditions known as sarcopenia and cachexia.
\end{abstract}

Sarcopenia, the age-related loss of muscle mass, is not a disease or a syndrome, it is not even a medical sign sometimes. Indeed, a general consensus among scientists does not exist regarding the definition and the identification criteria of this condition.

On the other hand, cachexia is a wasting syndrome characterized by an uncontrolled and unstoppable loss of muscle mass, associated with fatigue and weakness. It is often associated with a disease like cancer, AIDS, Chronic Obstructive Pulmonary Disease (COPD), multiple sclerosis, tuberculosis etc.

Given the complexity of these muscle conditions and considering that during aging and cancer there is an increased risk of comorbidities, regular physical activity might be a crucial point to be carefully evaluated on a single patient basis.

The aim of this review is to highlight the impact on society and the etiology of sarcopenia and cancer cachexia, with particular regard to the role played by physical activity in preventing and counteracting these muscle-wasting conditions, focusing attention also on the limitation factors that must be considered during the prescription of physical activity to sarcopenic and cachectic patients.

Key words: Sarcopenia, Cachexia, Muscle Tissue, Muscle Wasting, Physical Activity, Aging, Cancer.

\section{Sažetak}

Mišićno tkivo ima nekoliko važnih uloga po ljudsko zdravlje. Pored značajne mehaničke funkcije, ono predstavlja i najveći depo telesnih proteina. Osim toga, proizvodi i nekoliko miokina koji su, kroz interakcije sa drugim organima, u stanju da indukuju veoma bitne efekte. Gubitak mišićne mase ima izuzetan uticaj na zdravlje i ne iznenađuje činjenica da se sve više pažnje obraća na dva degenerativna, ireverzibilna i nezaustavljiva stanja, poznatija kao sarkopenija i kaheksija.

Sarkopenija, starosno zavisan gubitak mišićne mase, nije ni bolest ni sindrom, čak nekada nije ni medicinski znak. Konsenzus naučnika zapravo nije utemeljio preciznu definiciju, kao ni kriterijume u vezi sa ovim stanjem.

S druge strane, kaheksija predstavlja sindrom gubitka i karakteriše je nekontrolisan i nezaustavljiv gubitak mišićne mase, povezan sa umorom i slabošću. Često je povezana sa bolestima kao što su sindrom stečene imunodeficijencije (fr. syndrome d'immunodéficience acquise, SIDA), hronična opstruktivna bolest pluća (HOBP), multipla skleroza, tuberkuloza itd.

Imajući u vidu kompleksnost ovih stanja povezanih sa mišićnom masom, kao i činjenicu da je tokom starenja i u slučaju karcinoma povećan rizik od komorbiditeta, smatra se da redovna fizička aktivnost može da ima krucijalnu ulogu zbog koje bi je trebalo pažljivo oceniti, uzimajući u obzir svakog pacijenta pojedinačno.

Cilj ovog preglednog rada je da se naglase uticaj sarkopenije na društvo, kao i etiologija sarkopenije i kaheksije, koja je povezana sa rakom. Poseban akcenat će biti stavljen na ulogu koju fizička aktivnost može da ima u prevenciji i suzbijanju navedenih stanja (povezanih sa gubitkom mišićne mase), usredsređujući se i na faktore ograničenja koji se moraju uzeti u obzir prilikom propisivanja fizičke aktivnosti pacijentima sa sarkopenijom i kaheksijom.

Ključne reči: sarkopenija, kaheksija, mišićno tkivo, gubitak mišićne mase, fizička aktivnost, starenje, karcinom 


\section{Introduction}

The muscle mass represents the biggest reserve of body proteins; it plays different mechanical functions (movement, maintaining posture, breathing etc.) and can be considered, to all-purposes, a secretory organ (1). Interestingly, skeletal muscle produces different cytokines and peptides classified as "myokines" which are able to communicate with several organs simultaneously and to produce different benefits for health. Indeed, myokines exert either autocrine, endocrine or paracrine effects and their production is strongly associated with muscle mass and muscle contraction (2).

As human body ages, there is a gradual decrease in muscle mass. This age-related loss of contractile tissue is a serious threat for health and it is associated with a risk of adverse outcomes such as frailty, disability, chronic diseases and death (3). Given the tremendous impact on health, a great interest has raised on two degenerative, irreversible and unstoppable conditions known as sarcopenia and cachexia.

Sarcopenia is a term introduced in 1988, by Irwin Rosenberg and means: "flesh poverty" (4). This age-related loss of skeletal muscle starts early in adulthood (approximately at the age of 20) (5), accelerating after the age of 65 with more than $1 \%$ of muscle mass loss per year (6). Moreover, it is often related to other conditions as dynapenia (loss of muscle strength and power associated with a reduced movement capability) and cachexia (3). Sarcopenia is not a disease or a syndrome, it is not even a medical sign sometimes. Indeed, it is difficult for physicians to determine whether the loss of muscle mass is physiological rather than pathological (3). In 2009, numerous scientific societies such as the European Geriatric Medicine, the European Society for Clinical Nutrition and Metabolism, the International Association of Gerontology and Geriatrics-European Region and the International Association of Nutrition and Aging, challenged their efforts to form an European group to get a practical clinical definition and a diagnostic criteria for sarcopenia forming The European Working Group on Sarcopenia (EWGSOP). As explained in the next section, EWGSOP developed a clinical definition and consensus diagnostic criteria for the age-related sarcopenia, using both low muscle mass and low muscle functions (strength or performance) (7).

On the other hand, cachexia is a wasting syndrome, characterized by an uncontrolled and unstoppable loss of muscle mass, associated with fatigue and weakness. This condition is seen in patients with AIDS, Chronic Obstructive Pulmonary Disease (COPD), multiple sclerosis, tuberculosis and cancer (8). It is possible to identify three different stages of clinical relevance for cancer cachexia: pre-cachexia, cachexia and refractory cachexia (9). Pa- tients with an involuntary loss of body weight of $5 \%$ in 6 months or with a body mass index lower than $20 \mathrm{~kg} / \mathrm{m}^{2}$ are classified as having cachexia. In pre-cachexia, some symptoms (anorexia and impaired glucose tolerance) can accompany an involuntary loss of body weight lower than $5 \%$ in 6 months. Refractory cachexia is the last stage of this condition and is characterized by an intense catabolism, poor performance status and a life expectancy of a few months (10).

Currently, there are limited options to counteract the effects of muscle tissue loss as a part of aging or a disease process, except for lifestyle therapies like healthy nutrition and exercise training. The aim of this review is to highlight the impact on society and the etiology of sarcopenia and cancer cachexia with particular regard to the role played by physical activity, in preventing and counteracting these muscle-wasting conditions.

\section{Epidemiology of sarcopenia and cancer cachexia}

Despite the fact that the clinical definition and consensus about diagnostic criteria for age-related sarcopenia have been identified (7), it is still complicated to estimate the actual prevalence of sarcopenia and its impact on public health (11). Clear examples are presented in two different studies provided by Batsis et al. (12) and Bijlsma et al. (13), which compare the prevalence of sarcopenia using different definitions and diagnostic parameters. In particular, Batsis and colleagues found that sarcopenia ranges from $4.4 \%$ to $94 \%$ across definitions, while Bijlsma and collaborators, applying different diagnostic criteria to different age categories, found differences that range from $0 \%$ to $31.2 \%$ in the $60-69$ years group and from $0 \%$ to $45.2 \%$ in the over 70 years category. In its definition, EWGSOP integrates the loss of muscle mass, the loss of muscle strength and the loss of physical functions to identify the presence of sarcopenia, suggesting to adopt two standard deviations below the mean value of healthy young adults, as cut-off point for each field. According to this definition, at the World Congress on Osteoporosis, Osteoarthritis and Musculoskeletal Diseases, a research group from the University of Liège (Belgium) revealed dramatic numbers about the prevalence of sarcopenia in Europe, providing also some interesting projections. In 2016, the European citizens affected by sarcopenia there are 10869527 (11.1\% of older population) and this number will tend to the increase of 72.4\%, reaching a total of 18735173 sarcopenic people in 2045 (12.9\% of older population) (14).

Similarly to sarcopenia, cachexia, internationally recognized as a complex "multifactorial syndrome defined by an ongoing loss of skeletal muscle mass (with or without 
loss of fat mass) that cannot be fully reversed by conventional nutritional support and leads to progressive functional impairment" (9). Therefore, in agreement with this definition, epidemiological evidences show that cachexia affects $50 \%$ of cancer patients with a dramatic impact on quality of life, reducing the response to chemotherapy and even leading to death. In fact, it has been estimated that during cancer, more than $20 \%$ of patients die because of cachexia (15). Interestingly, the incidence of weight loss vary greatly according to the tumor site: the greatest weight loss was seen among patients with solid tumors (e.g. gastric, pancreatic, lung, colorectal, head and neck) (16). In particular, those patients with upper gastrointestinal and lung cancer are more predisposed to this condition with a prevalence of cachexia up to $80 \%$ and $60 \%$ respectively (17). Furthermore, patients with prostate or colon cancer experience cachexia in $50 \%$ of the cases while those with breast cancer or acute leukemia experience cachexia in $30 \%$ of cases (18).

\section{Etiology of sarcopenia and cancer cachexia}

Sarcopenia is characterized by a decline in muscle mass with aging, where the muscle fibers are substituted by non-contractile tissue such as intramuscular fat and connective tissue (19). Although their relative contribution is still unknown, there are multitude of concomitant "internal" and "external" causes that could lead to this altered muscle mass condition (Figure 1).

With regard to internal processes, the most important seems to be a reduced anabolic hormone production and sensitivity: in fact, aging is associated with lower Insu- lin-like Growth Factor 1 (IGF-1), insulin resistance and testosterone levels, as well as a reduced sensitivity of their targets (20). Indeed, it is known that these hormones are potent activators of Protein kinase B (Akt) signaling pathway, resulting in increased production and decreased degradation of muscle proteins, by inhibition of the Forkhead box (FoxO) pathway. Moreover, testosterone activity affects skeletal muscle tissue growth and differentiation through myoblast stimulation, inhibition of myostatin and satellite cells renewal (21). In addition, the increase of apoptotic activities in myofibers, the increase of pro-inflammatory cytokines, the changes of muscle mitochondrial functions and the accumulation of free radicals, as well as the decline in the number of motor neurons (in particular of alpha-motor neurons) and a reduction of synaptic vesicles are all important contributors of muscle wasting in sarcopenia. $(6,22)$. Among external influences, those that could be able to drive the pathophysiological changes leading to muscle loss are "disuse or immobility" and a deficient intake of energy and proteins. It is important to consider that older people are among the most sedentary and physically inactive segment of society (23). As people age, they become less active and this places them inside a tremendous vicious cycle (figure 2) in which there is not only an increased loss of muscle mass but also an increased risk of disability, morbidities and premature death (24).

Similarly to sarcopenia, even the cachexia syndrome shows a systemic inflammation state (25). In fact, an imbalance between pro-inflammatory and anti-inflammatory cytokines is currently believed to contribute to cachexia (26). Moreover, other pathophysiological mechanisms

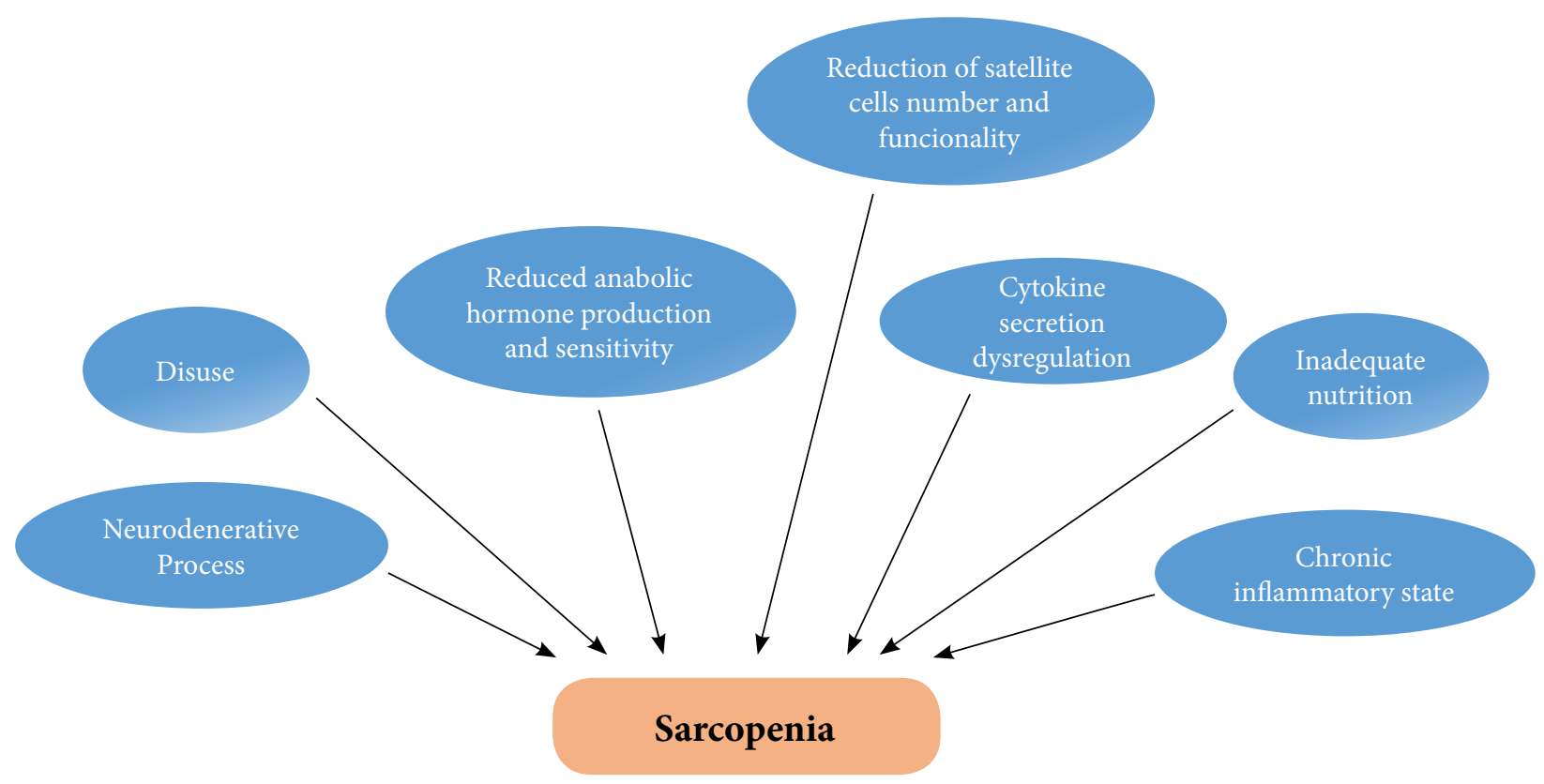

Figure 1. Sarcopenia is a complex condition mediated by different causes that interact to generate muscle wasting. 


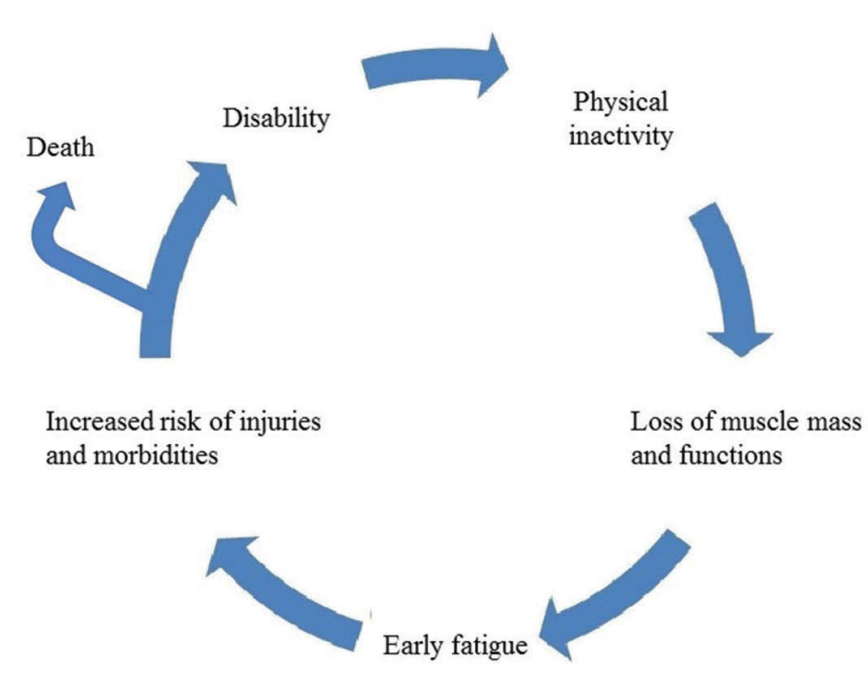

Figure 2: Entering in the physical inactivity vicious cycle has a tremendous impact on people quality of life. It provokes several detrimental effects and could leads to disability and death.

are shared with sarcopenia, such as the down-regulation of anabolic factors/pathways including IGF-1, androgens and satellite cells proliferation, as well as an increase in catabolic pathways such as apoptosis, autophagy and mitochondrial dysfunction (mitophagy) $(6,20,21)$. Cachexia can also result from a reduced availability of nutrients; in fact, it is noteworthy that, while not all malnourished patients are cachectic, all cachectic patients are invariably malnourished. Therefore, together with the inflammatory imbalance, this state of malnutrition leads eventually to accumulation of damaging free radical that are known as reactive oxygen species (ROS), such as hydroxyl radicals, superoxide radicals and others (27). Reactive oxygen species are chemically reactive molecules containing oxygen with an unpaired electron and this conformation gives them the possibility to interact with different other molecules (28). These molecules are considered regulators of cellular functions during inflammatory response, but an over-accumulation beyond a certain threshold, can have different detrimental effects (29). ROS activity can last for days in absence of an adequate antioxidant response and these species can move outside the cell and react with other tissues provoking oxidative stress (30). To date, oxidative stress plays a key role in tissue degeneration and, consequently, in systems dysfunctions; ROS accumulation seems to be the potential trigger of many chronic diseases (31).

\section{Exercise as a tool to counteract sarcopenia and cancer-related cachexia}

Sarcopenia and cachexia are complex conditions in which many systems are involved simultaneously. Hormonal and drugs supplementation are palliative solutions to counteract the effects of these two degenerative pathways $(32,33)$. On the other hand, physical activity seems to be the most effective treatment in preventing and counteracting age and cancer-related muscle tissue loss. It is widely known that physical activity is a panacea able to prevent and treat multiple age-related diseases (34) even in elders that have been inactive for the majority of their life (35). In the light of this, many studies have focused their attention on the effects of physical activity on prevention and treatment of sarcopenia, but only few studies have investigated the impact of exercise training on precachectic and cachectic patients (36).

Physical activity produces many healthful benefits but, at the same time, it carries some risks: these types of interventions, in particular in elderly, must be carried out considering the patients profile and must be supervised

\section{Cachexia}

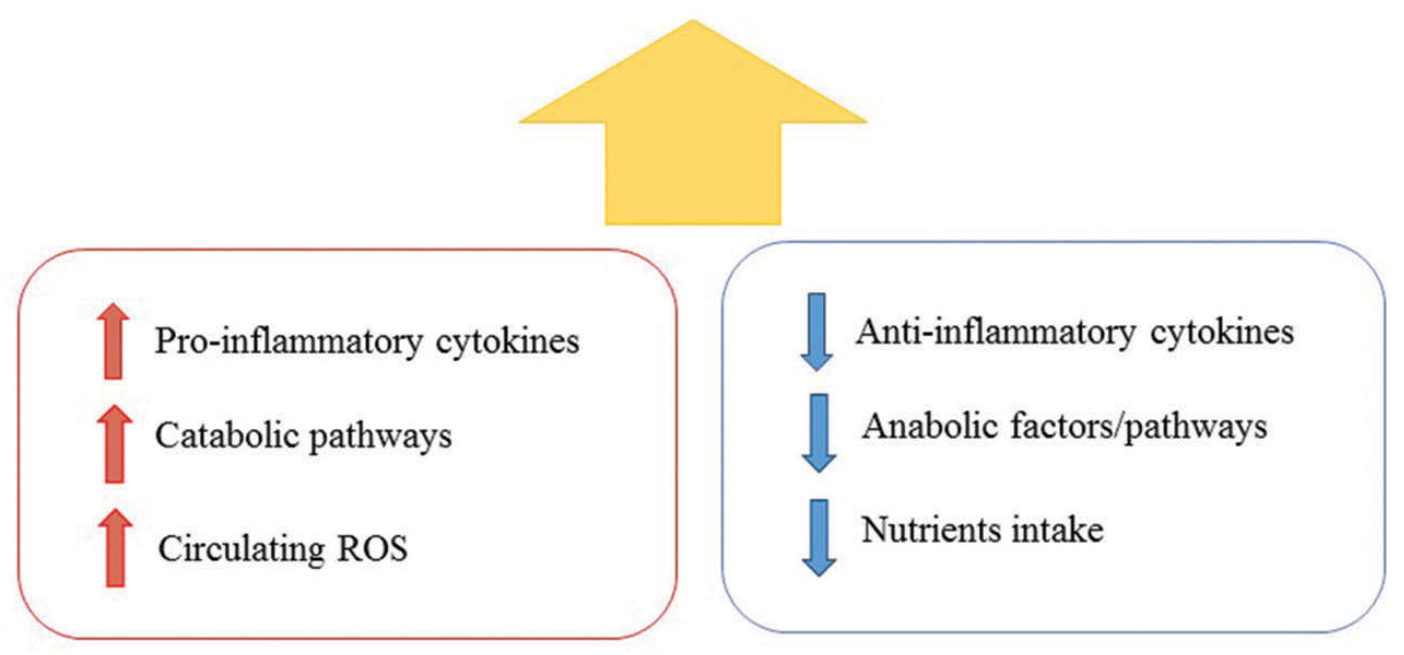

Figure 3: Cachexia is a multifactorial process determined by different bio-functional alterations of homeostasis. 
by experts of the field and started after a careful medical screening. Prescribing physical activity to cancer patients is an extremely delicate process. Physicians must consider the complete medical case and the relative limitations associated with the pathology and the therapy. As for example, anemia is an important limiting factor to the participation in physical activities. Indeed, the concomitant presence of this condition, which affect one third of cancer patients at diagnosis (37), when participating in physical activities could be both dangerous and deleterious for patients, as demonstrated by Argilés and colleagues (38) in tumor bearing mice, where the health conditions of anemic animals worsen after exercise. It is, therefore, advisable to immediately interrupt any extra activity different from daily life, when anemia is present $(38,39)$. Despite anemia which is an important limitation factor to the participation in regular physical activity in cancer patients, there are many other aspects that must be taken into account during exercise prescription. It is necessary to consider that patients with compromised immune functions, that complete a bone marrow transplant, should avoid public places for at least 1 year after the transplantation and that the exposure to chlorine (swimming pool activities) after radioactive treatments could cause skin irritations (39).

In the end, it is important to consider that cachectic patients are overexposed to the risk of muscle dislodgment and an adequate warm-up and load progression are fundamental aspects of exercise prescription (39). Noteworthy, during chemotherapy and radiation, most patients feel a general sense of fatigue. This tiredness does not get better with rest, but at the same time could severely limit the participation in physical activity programs. The NCCN Clinical Practice Guidelines in Oncology (NCCN Guidelines $^{\circledR}$ ) for Cancer-Related Fatigue, suggest to physicians and sport scientists to start slowly and progressively increase the intensity and duration of the exercises, to avoid injuries and dropout.

A clear consensus regarding exercise recommendations for sarcopenic and cachectic patients do not exist. Anyway, the American College of Sport Medicine (ACSM) and the American Heart Association (AHA) provide some guidelines for adults over 65 years of age that could be applied, with the proper precautions, to both sarcopenic and cachectic groups (40).

To counteract muscle wasting and, in particular, the loss of muscle functions associated with sarcopenia and cachexia, ACSM and AHA suggest to integrate aerobic, resistance and flexibility training to routine activities of daily living of light or moderate intensity (e.g., self-care, cooking, casual walking or shopping etc.).
Aerobic training is any type of exercise that stimulates and strengthens the heart and lungs functions and improves the body's oxygen utilization. It is an important physiological stimulus able to induce many functional improvements extending life expectancy, reducing the risk of many chronic disorders and orchestrating numerous adaptation in skeletal muscles (see below) (41; 42). During this type of activities, such as walking, jogging and running, tissue metabolism uses oxygen at a rate at which the cardio respiratory system can replenish it in the working muscles.

ACSM and AHA recommend the participation in moderate-intensity aerobic training for a minimum of 30 minutes on five days each week (150 min/week) or vigorous-intensity aerobic activity for a minimum of 20 minutes on three days each week (60 min/week). Moderate-intensity aerobic activities produce a great increase in heart rate and breathing and, on a scale where 0 represents "no load" and 10 an "all-out effort", they represent a 5 or 6 . On the other hand, vigorous intensity activities produce a large increase in heart rate and breathing and, on the same scale, represent 7 or 8 (43).

Several studies have shown the effectiveness of resistance training in improving muscle mass and functions. This type of training is "a form of physical activity designed to improve muscular fitness by exercising a muscle or a muscle group against external resistance" (44). ACSM and AHA recommend, at least, two resistance-training sessions per week (to be performed in non-consecutive days to ensure enough recovery time) in which all the six major muscle groups must be involved (chest, shoulders, arms, back, abdomen and legs). Different types of resistance training are described in literature, differing from each other regarding the intensity, the number of repetitions and the velocity of execution. ACSM and AHA suggest a slow-moderate intensity resistance training performed with a resistance (weight) that allows 10 to 15 repetitions at $65-70 \%$ of one repetition maximum (1RM), performing the concentric and eccentric phase in 2-3 seconds for each muscle contraction. This type of training is effective in increasing muscle strength but seems to be less effective in increasing muscle mass and power $(43,45,46)$. In order to allow the proper progression, ACSM recommend to progressively increase the load according to the improvements made by the patients and in consideration of specific strength tests that must be performed frequently and constantly to estimate the 1 Repetition Maximum (1RM; index of maximal strength).

The loss of the muscle power, closely associated with muscle wasting, is a significant predictor of performing activities of daily living (i.e., getting dressed, cooking, carrying groceries, climbing stairs, etc.). To train muscle 
power, the exercise protocols shall include 3 to 6 repetitions with an intensity higher than $80 \%$ of $1 \mathrm{RM}$ with a concentric phase performed as quickly as possible and an eccentric phase duration of approximately 2 seconds for each muscle contraction (45).

Finally, in order to reduce the risk of falls and subsequent debilitating injuries, ACSM and AHA suggest to integrate aerobic and resistance training with exercises focus on maintaining and improving balance and flexibility every day for at least 10 minutes (43).

Different molecular adaptations in multiple tissues underline the benefits determined by physical activity in both sarcopenic and cachectic subjects. Various signals, including $\mathrm{Ca}^{2+}$ and adenosine monophosphate (AMP), are activated by aerobic exercise. These signals activate intracellular pathways such as calcium/calmodulin-dependent protein kinase (CaMK) and AMP-activated protein kinase (AMPK) that lead to an increase of mitochondrial genes activity (47). One of the most important regulators of mitochondrial biogenesis is the peroxisome proliferation activated receptor gamma co-activator - $1 \alpha$ (PGC-1 $\alpha$ ) whose production is strongly induced by aerobic exercise $(48,49)$. Therefore, executing aerobic activities, the improved muscle mitochondrial content and efficiency, improves the capacity to cope with oxidative stress and optimize exercise capacity (50). Indeed, this type of exercise might not only counteract the reduction of oxidative capacity found in experimental cachexia (51), but it also stimulates the oxidative metabolism to prevent hyperlipidemia and, consequently, ameliorate the insulin resistance. Interestingly, aerobic exercise can also increase the skeletal muscle insulin sensitivity (52) increasing glucose transporters (GLUT 1-4) expression and activity. Although the mechanisms behind are still unknown, it seems that this increased insulin sensitivity could reduce the muscle protein breakdown (53).

On the other side, an intriguing hypothesis about the mechanism of action of resistance training foresees that this type of training is able to exert its effect on transcriptome and, in particular, Raue and colleagues (54) found that 661 genes were responsive to resistance exercise and that they correlated with the increase in whole

\section{References}

1. Wolfe RR. The underappreciated role of muscle in health and disease. Am J Clin Nutr. 2006;84(3):475-82.

2. Pedersen BK. Muscles and their myokines. J Exp Biol. 2011;214(Pt 2):337-46.

3. Visser M. Towards a definition of sarcopenia--results from epidemiologic studies. J Nutr Health Aging. 2009;13(8):713-6.

4. Rosenberg $\mathrm{IH}$, Roubenoff R. Stalking sarcopenia. Ann Intern Med. 1995;123(9):727-8. 5. Mazzeo, R. S. (2003). Exercise and the Older Adult. ACSM's Fit Society Page, 1-3. muscle size and strength. In addition, it has been widely demonstrated that resistance training enhances the rate of mixed muscle protein synthesis in older participants guarantying an effective muscle proteins turnover and reducing muscle wasting $(55,56,57)$. Moreover, several studies agree with the idea that physical activity can exerts important functions against many other age-related markers improving the general adaptive response of specific anti-oxidant and stress proteins (58).

\section{Conclusion}

It is known that weight and muscle loss are associated with frailty, loss of independence and increased mortality. The population most affected by these wasting syndromes and their unfavorable consequences are elderly and cancer patients. Despite many efforts carried out by the scientific community to identify proper tests (i.e. postural balance, gait speed, handgrip strength, leg extension, measures of body composition and global physical function), to date, sarcopenia and cachexia in the majority of patients are not identified until the disease is advanced. In particular, cachexia is a condition that may be present in the early stages of tumor growth and sometimes before any signs or symptoms of malignancy (59). Currently, there are limited options to counteract the effects of muscle mass loss as a part of aging or a disease process, except for lifestyle therapies like physical activity.

Given the complexity of these muscle conditions and considering that during aging and cancer there is an increased risk of comorbidities, the exercise dose should be a crucial point to be carefully evaluated on a single patient basis.

In this review, we have presented some of the beneficial effects that physical activity could produce in counteracting sarcopenia and cancer cachexia. Indeed, physical activity seems to be the most effective method to treat these degenerative conditions, producing many benefits with very few side effects. Therefore, considering both the maintenance of muscle mass and the aforementioned molecular effects induced by different motor intervention protocols, a combination of aerobic and resistance exercise rather than only one of them appears to be preferred.

5. Kim TN, Choi KM. Sarcopenia: definition, epidemiology, and pathophysiology. J Bone Metab. 2013;20(1):1-10.

6. Cruz-Jentoft AJ, Baeyens JP, Bauer JM, Boirie Y, Cederholm T, Landi F, et al. Sarcopenia: European consensus on definition and diagnosis: Report of the European Working Group on Sarcopenia in Older People. Age Ageing. 2010;39(4):412-23.

7. Payne C, Wiffen PJ, Martin S. Interventions for fatigue and weight loss in adults with advanced progressive illness. Cochrane Database Syst Rev. 2012;1:CD008427. 
8. Fearon K, Strasser F, Anker SD, Bosaeus I, Bruera E, Fainsinger RL, et al. Definition and classification of cancer cachexia: an international consensus. Lancet Oncol. 2011;12(5):489-95.

9. Mueller TC, Burmeister MA, Bachmann J, Martignoni ME. Cachexia and pancreatic cancer: are there treatment options? World J Gastroenterol. 2014;20(28):9361-73.

10. Beaudart $C$, Rizzoli R, Bruyère $O$, Reginster JY, Biver E. Sarcopenia: burden and challenges for public health. Arch Public Health. 2014;72(1):45.

11. Batsis JA, Barre LK, Mackenzie TA, Pratt SI, Lopez-Jimenez F, Bartels SJ. Variation in the prevalence of sarcopenia and sarcopenic obesity in older adults associated with different research definitions: dual-energy X-ray absorptiometry data from the National Health and Nutrition Examination Survey 1999-2004. J Am Geriatr Soc. 2013;61(6):974-80.

12. Bijlsma AY, Meskers CG, Ling CH, Narici M, Kurrle SE, Cameron ID, et al. Defining sarcopenia: the impact of different diagnostic criteria on the prevalence of sarcopenia in a large middle aged cohort. Age (Dordr). 2013;35(3):871-81.

13. Kanis JA, Cosman F. Osteoporosis international with other metabolic bone diseases. In 2016. p. 614.

14. Vaughan VC, Martin P, Lewandowski PA. Cancer cachexia: impact, mechanisms and emerging treatments. J Cachexia Sarcopenia Muscle. 2013;4(2):95-109.

15. Tan BH, Fearon KC. Cachexia: prevalence and impact in medicine. Curr Opin Clin Nutr Metab Care. 2008;11(4):400-7.

16. Fox KM, Brooks JM, Gandra SR, Markus R, Chiou CF. Estimation of Cachexia among Cancer Patients Based on Four Definitions. J Oncol. 2009;2009:693458.

17. Del Fabbro E, Inui A, Strasser F. Cancer Cachexia. Pocket book for cancer supportive care. New York: Springer Healthcare; 2012.

18. Muscaritoli M, Anker SD, Argilles J, Aversa Z, Bauer JM, Biolo G, et al. Consensus definition of sarcopenia, cachexia and pre-cachexia: Joint document elaborated by Special Interest Groups (SIG) " cachexia-anorexia in chronic wasting diseases" and " nutrition in geriatrics." Clin Nutr. 2010;29(2):154-9.

19. Drey M. Sarcopenia - pathophysiology and clinical relevance. Wien Med Wochenschr. 2011;161(17-18):402-8.

20. Bhasin S, Taylor WE, Singh R, Artaza J, Sinha-Hikim I, Jasuja R, et al. The mechanisms of androgen effects on body composition: mesenchymal pluripotent cell as the target of androgen action. J Gerontol A Biol Sci Med Sci. 2003;58(12):M1103-10.

21. Jackson MJ. Reactive oxygen species in sarcopenia: Should we focus on excess oxidative damage or defective redox signalling? Mol Aspects Med [Internet]. 2016;2016.

22. Dillin A, Gottschling DE, Nyström T. The good and the bad of being connected: the integrons of aging. Curr Opin Cell Biol. 2014;26:107-12.

23. Spirduso W, Francis K, MacRae P. Physical dimensions of aging. Hum Kinet M. 2nd Editio. Champaign, IL (USA): Human Kinetics; 2005;384.

24. Meng SJ, Yu LJ. Oxidative stress, molecular inflammation and sarcopenia. Int J Mol Sci. 2010;11(4):1509-26.

25. Deans C, Wigmore SJ. Systemic inflammation, cachexia and prognosis in patients with cancer. Curr Opin Clin Nutr Metab Care. 2005;8(3):265-9

26. Khare M, Mohanty C, Das BK, Jyoti A, Mukhopadhyay B, Mishra SP. Free radicals and antioxidant status in protein energy malnutrition. Int $\mathrm{J} \mathrm{Pe}$ diatr. 2014;2014:254396.

27. Gilbert S. Developmental biology. Associates S, editor. Methods [Internet]. 6 th editio. Sunderland (MA); 2014;66(3):363-4.

28. Corbi G, Conti V, Russomanno G, Longobardi G, Furgi G, Filippelli A, et al. Adrenergic signaling and oxidative stress: a role for sirtuins? Front Physiol. 2013;4:324.

29. Pietrangelo T, Di Filippo ES, Mancinelli R, Doria C, Rotini A, Fanò-Illic G, et al. Low Intensity Exercise Training Improves Skeletal Muscle Regeneration Potential. Front Physiol. 2015;6:399.

30. Bouzid MA, Hammouda O, Matran R, Robin S, Fabre C. Changes in ox idative stress markers and biological markers of muscle injury with aging at rest and in response to an exhaustive exercise. PLoS One. 2014;9(3):e90420.
31. Sakuma K, Yamaguchi A. Sarcopenia and age-related endocrine function. Int J Endocrinol. 2012;2012:127362.

32. Aoyagi T, Terracina KP, Raza A, Matsubara H, Takabe K. Cancer cachexia, mechanism and treatment. World J Gastrointest Oncol. 2015;7(4):17-29.

33. Hubbard BP, Sinclair DA. Small molecule SIRT1 activators for the treatment of aging and age-related diseases. Trends Pharmacol Sci. 2014;35(3):146-54

34. Cvecka J, Tirpakova V, Sedliak M, Kern H, Mayr W, Hamar D. Physical Activity in Elderly. Eur J Transl Myol. 2015;25(4):249-52.

35. Bowen TS, Schuler G, Adams V. Skeletal muscle wasting in cachexia and sarcopenia: molecular pathophysiology and impact of exercise training. J Cachexia Sarcopenia Muscle. 2015;6(3):197-207.

36. Knight K, Wade S, Balducci L. Prevalence and outcomes of anemia in cancer: a systematic review of the literature. Am J Med. 2004 Apr;116(7):11-26.

37. Argilés JM, Busquets S, López-Soriano FJ, Costelli P, Penna F. Are there any benefits of exercise training in cancer cachexia? J Cachexia Sarcopenia Muscle. 2012;3(2):73-6.

38. Doyle C, Kushi LH, Byers T, Courneya KS, Demark-Wahnefried W, Grant $B$, et al. Nutrition and physical activity during and after cancer treatment: an American Cancer Society guide for informed choices. CA Cancer J Clin. 2006;56(6):323-53.

39. Montero-Fernández N, Serra-Rexach JA. Role of exercise on sarcopenia in the elderly. Eur J Phys Rehabil Med. 2013;49(1):131-43.

40. Lindholm ME, Marabita F, Gomez-Cabrero D, Rundqvist H, Ekström TJ, Tegnér J, et al. An integrative analysis reveals coordinated reprogramming of the epigenome and the transcriptome in human skeletal muscle after training. Epigenetics. 2014;9(12):1557-69.

41. Saleem A, Safdar A. Exercise-induced histone acetylation - playing tag with the genome. J Physiol. 2010;588(Pt 6):905-6.

42. Nelson ME, Rejeski WJ, Blair SN, Duncan PW, Judge JO, King AC, et al. Physical activity and public health in older adults: recommendation from the American College of Sports Medicine and the American Heart Association. Circulation. 2007;116(9):1094-105.

43. Esco M. Resistance Training for Health and Fitness. Am Coll Sport Med. 2013;1-2.

44. Iolascon G, Di Pietro G, Gimigliano F, Mauro GL, Moretti A, Giamattei $M T$, et al. Physical exercise and sarcopenia in older people: position paper of the Italian Society of Orthopaedics and Medicine (OrtoMed). Clin Cases Miner Bone Metab. 2014;11(3):215-21.

45. Yu J. The etiology and exercise implications of sarcopenia in the elderly. Int J Nurs Sci. Elsevier Ltd; 2015;2(2):199-203.

46. Hawley JA, Tipton KD, Millard-Stafford ML. Promoting training adaptations through nutritional interventions. J Sports Sci. 2006;24(7):709-21.

47. Lira VA, Benton CR, Yan Z, Bonen A. PGC-1alpha regulation by exercise training and its influences on muscle function and insulin sensitivity. Am J Physiol Endocrinol Metab. 2010;299(2):E145-61.

48. Baldwin KM, Haddad F. Research In the Exercise Sciences; Where We Are and Where Do We Go From Here: Part II? Natl Inst Heal. 2011;38(2):42-50.

49. Vincent G, Lamon S, Gant N, Vincent PJ, MacDonald JR, Markworth JF, et al. Changes in mitochondrial function and mitochondria associated protein expression in response to 2-weeks of high intensity interval training. Front Physiol. 2015;6:51.

50. White JP, Baynes JW, Welle SL, Kostek MC, Matesic LE, Sato S, et al. The regulation of skeletal muscle protein turnover during the progression of cancer cachexia in the Apc(Min/+) mouse. PLoS One. 2011;6(9):e24650.

51. Hawley JA, Lessard SJ. Exercise training-induced improvements in insulin action. Acta Physiol (Oxf). 2008;192(1):127-35.

52. Gordon BS, Kelleher AR, Kimball SR. Regulation of muscle protein synthesis and the effects of catabolic states. Int J Biochem Cell Biol. 2013;45(10):2147-57.

53. Raue U, Trappe TA, Estrem ST, Qian HR, Helvering LM, Smith RC, et al. Transcriptome signature of resistance exercise adaptations: mixed muscle and fiber type specific profiles in young and old adults. J Appl Physiol (1985). 2012;112(10):1625-36 
54. Yarasheski KE, Pak-Loduca J, Hasten DL, Obert KA, Brown MB, Sinacore DR. Resistance exercise training increases mixed muscle protein synthesis rate in frail women and men $>/=76 \mathrm{yr}$ old. Am J Physiol. 1999;277(1 Pt 1):E118-25.

55. Frontera WR, Meredith CN, O'Reilly KP, Knuttgen HG, Evans WJ. Strength conditioning in older men: skeletal muscle hypertrophy and improved function. J Appl Physiol (1985). 1988;64(3):1038-44.

56. Fry CS, Drummond MJ, Glynn EL, Dickinson JM, Gundermann DM, Timmerman $\mathrm{KL}$, et al. Skeletal muscle autophagy and protein breakdown following resistance exercise are similar in younger and older adults. $J$ Gerontol A Biol Sci Med Sci. 2013;68(5):599-607.

57. Beltran Valls MR, Dimauro I, Brunelli A, Tranchita E, Ciminelli E, Caserotti $P$, et al. Explosive type of moderate-resistance training induces functional, cardiovascular, and molecular adaptations in the elderly. Age (Dordr). 2014;36(2):759-72.

58. Jurdana M. Cancer cachexia-anorexia syndrome and skeletal muscle wasting. Radiol Oncol. 2009;43(2):65-75. 